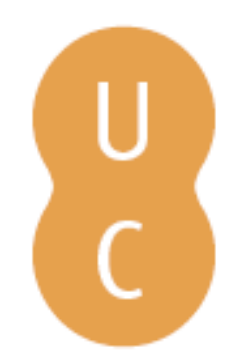

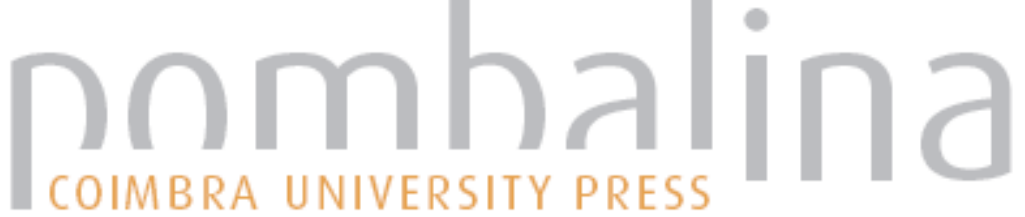

\section{Intimate partner homicide-suicide a 5-year case review (2004-08)}

Autor(es): $\quad$ Pereira, A. R.; Alves, L. Ferreira; Ribeiro, I. Pinto; Santos, J. Costa Publicado por: Imprensa da Universidade de Coimbra; International Academy of Legal

URL

persistente: URI:http://hdl.handle.net/10316.2/31818

DOI: $\quad$ DOI:http://dx.doi.org/10.14195/978-989-26-0173-1_42

Accessed : $\quad$ 26-Apr-2023 12:20:59

A navegação consulta e descarregamento dos títulos inseridos nas Bibliotecas Digitais UC Digitalis, UC Pombalina e UC Impactum, pressupõem a aceitação plena e sem reservas dos Termos e Condições de Uso destas Bibliotecas Digitais, disponíveis em https://digitalis.uc.pt/pt-pt/termos.

Conforme exposto nos referidos Termos e Condições de Uso, o descarregamento de títulos de acesso restrito requer uma licença válida de autorização devendo o utilizador aceder ao(s) documento(s) a partir de um endereço de IP da instituição detentora da supramencionada licença.

Ao utilizador é apenas permitido o descarregamento para uso pessoal, pelo que o emprego do(s) título(s) descarregado(s) para outro fim, designadamente comercial, carece de autorização do respetivo autor ou editor da obra.

Na medida em que todas as obras da UC Digitalis se encontram protegidas pelo Código do Direito de Autor e Direitos Conexos e demais legislação aplicável, toda a cópia, parcial ou total, deste documento, nos casos em que é legalmente admitida, deverá conter ou fazer-se acompanhar por este aviso.

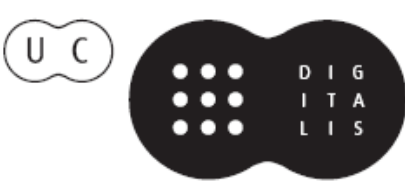




\section{Duarte Nuno Vieira Anthony Busuttil \\ Denis Cusack • Philip Beth}
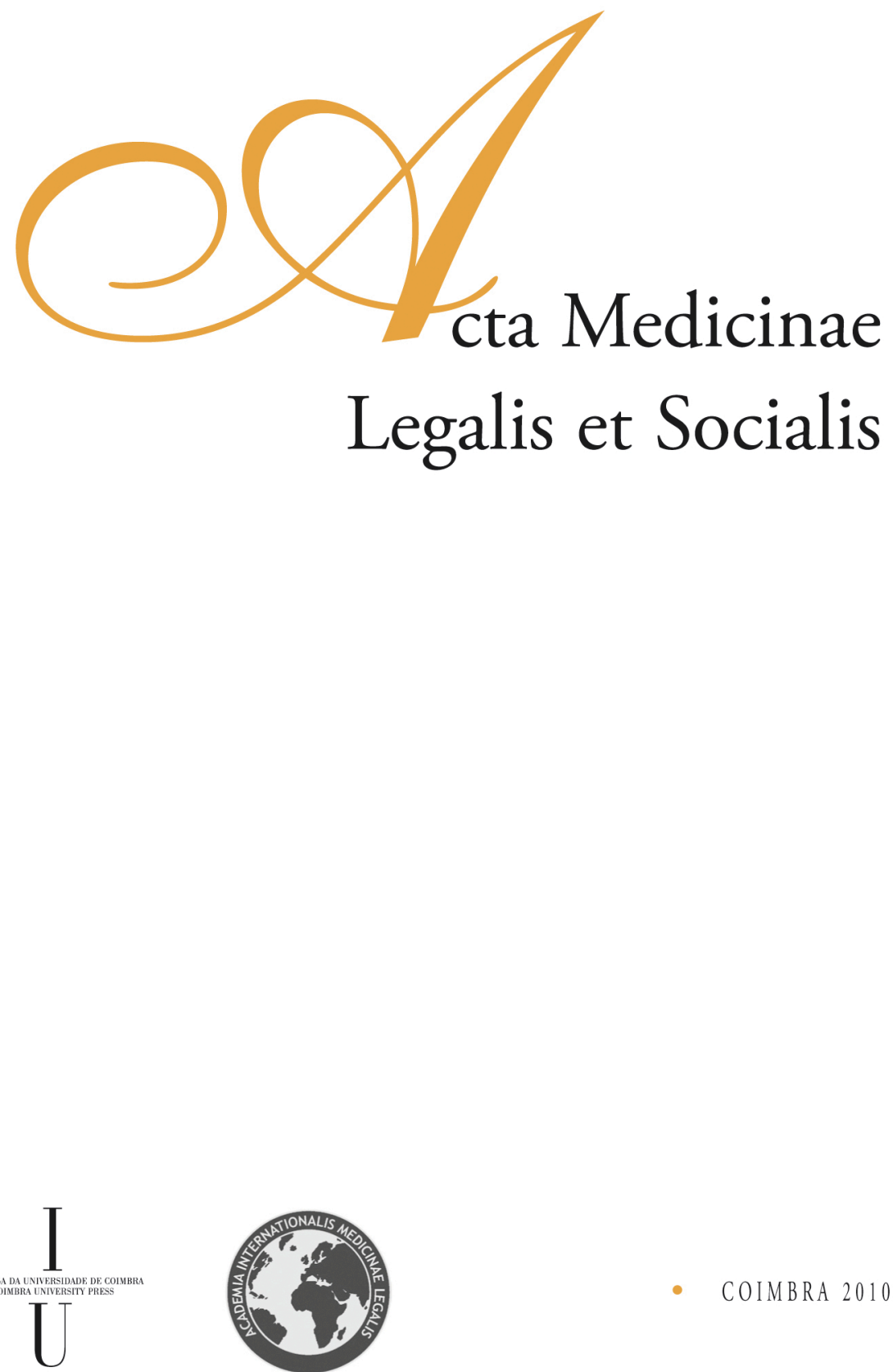
A. R. Pereira ${ }^{1}$, L. Ferreira Alves ${ }^{2}$, I. Pinto Ribeiro ${ }^{2}$, J. Costa Santos ${ }^{2}$

${ }^{1}$ Centre Branch of the National Institute of Legal Medicine, Coimbra, Portugal

${ }^{2}$ South Branch of the National Institute of Legal Medicine, Lisbon, Portugal

\title{
INTIMATE PARTNER HOMICIDE-SUICIDE \\ A 5-YEAR CASE REVIEW (2004-08) ${ }^{1}$
}

\begin{abstract}
Homicide followed by suicide is an extremely rare tragic incident, specially in the context of intimate partner violence. The aim of this 5-year retrospective study, from 2004 to 2008, in the Lisbon area, is to provide a better understanding, in a medicolegal perspective, of intimate/partner homicide-suicide. Database of the Department of Forensic Pathology was analysed concerning all the incidents involving at least a female homicide victim and a related suicide or suicide attempt. According to our study, 54\% of all intimate partner homicides were followed by suicide (71\%) or suicide attempts (29\%); $71 \%$ with one single victim and 29\% were double homicide with involvement of children/young adults; in most cases, the male homicide perpetrator was older and married to the victim; the majority of incidents occurred at the victim's home; firearms were used in most cases, to both homicide and suicide, with the same single anatomic location injuries in the head area. The results gathered are in accordance with other similar studies, and point towards the importance of prevention programs and the enforcement of existing domestic violence laws.
\end{abstract}

Keywords: Intimate partner homicide-suicide; partner violence; forensic pathology.

\section{Introduction}

Homicide followed by suicide is an extremely rare tragic incident committed by an individual who subsequently commits suicide within one week of the homicide [1]. Despite the low rate of ocurrence, homicide-suicide incidents are of great concern, specially in the context of intimate partner violence. Intimate/partner homicide-suicide is considered the most extreme form and consequence of intimate partner violence [2], because they often result in the death of family members, young children, and cause an additional morbidity and family disruption [3].

Previous studies of homicide-suicide incidents shows that usually these include one female victim and one male perpetrator, with a current or former intimate relationship between them [4], being the most typical, a man shooting a family member during

\footnotetext{
${ }^{1}$ Preliminary results presented at the XXI Congress of the International Academy of Legal Medicine, May 2009, Lisbon - Portugal.
} 
a separation process [5]. A substancial proportion includes the homicide of a child, and a small proportion can be attributed to "mercy" killings [4]. People who commit homicide have a high death risk themselves and are especially prone to suicide [5]. Between $18 \%$ and $40 \%$ of perpetrators of intimate femicide commit suicide afterwards [2]. Most suicides occurr at the same location as at least one of the homicides [1], with homicides taking place in the victim's home [4]. Firearms, specially handguns, are more likely to be used for both homicides and suicides and only in a minority of cases the offender uses a different weapon for homicide and suicide [3,5]. Amongst suicides, the head, face or neck are the most frequent locations of single wounds, while in homicides, the head is also the most common location with more multiple wounds locations than in suicides [3]. Alcohol or drug use is a common risk factor in homicides, independent of the suicide of the perpetrator [6].

The aim of this 5-year retrospective study, from 2004 through 2008, in the Lisbon Area, therefore, is to provide contextual information and a better understanding of intimate/partner homicide-suicide incidents concerning Portuguese population. Thus, the author's purpose was to analyse sociodemographic, clinical and medico-legal aspects of both victims and perpetrators involved in these kind of deaths.

\section{Materials and methods}

Intimate partner homicide-suicide were identified, after scanning the South branch database of the National Institute of Legal Medicine of Portugal (NILMP), related to Forensic Pathology Department and Lisbon area, over a 5-year period, between January 1, 2004 and December 31, 2008.

All the incidents involving at least a female intimate partner victim of homicide, with 18 years-old or more, and one male perpetrator that committed suicide or suicide attempt, within one week after the homicide(s) were identified. The expression "intimate partners" includes: spouses by marriage, common-law spouses, girlfriends, ex-intimate partners and extramarital consort. The incidents in which the perpetrator was not an intimate partner of the victim were excluded. Cases involving male intimate partner victims were not searched. Cases were reviewed and data collected from the medicolegal autopsy records, and other information (police, newspaper, etc.) when available.

In order to compare perpetrators and intimate partner victims characteristics, the following variables were sistematically analysed: sociodemographics aspects (gender, age and race/ethnic group); nature of the relationship; circumstances of death, precipitating factors and motivations if available; location of incident; autopsy results (location and type of fatal injuries; type of weapon) and toxicological information.

\section{Results}

During the 5-years examined, a total of 6.696 autopsies were performed at the Forensic Pathology Department of the NILMP South Branch. Of almost 57 female homicide victims, 26 cases (46\%) were considered intimate partner homicides. Out of these 26 cases, 14 (54\%) were identified as homicide-suicide incidents: 10 homicides 
(71\%) followed by suicides and $4(29 \%)$ by suicide attempts of the perpetrator. Of all 14 homicide-suicide incidents, the offender killed one victim in 10 cases (including all the cases of suicide attempts), and two victims in 4 cases, accounting a total of 28 deaths. Table 1 provides a comparison of all homicide victim(s) and perpetrators characteristics found.

\section{Perpetrators}

All the 14 perpetrators were male with a medium age of 55 years-old (range 33 to 79). Of the 10 males who committed suicide, all but one were white. Suicide was completed in 10 cases, the majority by firearm injuries ( 5 cases with handguns and 4 cases with shotguns) and the other suicide was due to a fall from height. Of the 4 cases of suicide attempts, a sharp instrument was used in 2 cases and a handgun in other 2. In 3 incidents, the perpetrator used a different weapon for homicide and subsequent suicide (shotgun and handgun/shotgun, manual strangulation/fall from the height, manual strangulation/sharp instrument for suicide attempt). Considering only firearm injuries in completed suicides or suicide attempts (11 cases), all of them were located in the head including 9 cases with single anatomic location. In other hand, 3 cases were quite different in homicide versus suicide, with multiple injuries in female victims and single ones in male perpetrators. All but one suicides occurred in the same place of the homicides. Two males tested positive for benzodiazepines and only one had a blood alcohol level of $0,63 \mathrm{~g} / \mathrm{l}$. Out of the 4 cases of attempted suicide, only one offender had a history of previous attempts.

\section{Female Victims}

Concerning female intimate partners, the victims had a medium age of 48 years-old (range 21 to 80 ) and all but one were white people. All but one females were younger than their intimate partner perpetrator.

Females were current or former intimate partners of the perpetrator: 9 spouses by marriage or common-law spouses; 3 ex-intimate partners (including spouses and girlfriends) and 2 extramarital consort. Except 3 cases (including those within extramarital consort), the majority were cohabitating with the perpetrator at the time of the incident. In 11 incidents (79\%), the perpetrators used a firearm for homicide, in 2 manual strangulation, and in 1 a sharp instrument. Among firearms, handguns were more likely to be used (7 cases) than shotguns (3 cases), with 1 case where both type of guns were used. Most female victims (64\%) died as result of firearm injuries on the head, $57 \%$ single located. Only one female had passive and active defense wounds. $72 \%$ of the female homicides took place in the victim's home while the others occurred outside home. In 4 cases benzodiazepines were detected. One of the cases of suicide attempt, the female victim had physical health problems (submitted to cancer surgery, Alzheimer's disease and bedridden) that could be attributed to "mercy" killing. 


\section{Other Victims}

Four homicide victims of the total homicide-suicide incidents comprised males: 2 children and 2 young adults, with a medium age of 20 years-old (range 8 to 34), all white, killed in the same event as their mothers. All but one were perpetrators offspring, the exception being an ex-step-son. In all 4 cases, firearms were used, mostly handguns (3 cases) and injuries were located in the head. In all cases, the victims were living at the same house of the perpetrators and the homicide took place at home.

\section{Discussion and conclusions}

In substance, the findings of this study are in accordance with other similar studies. In fact, the review of the literature show that over than $30 \%$ of all male perpetrators/ offenders of intimate partner homicide ultimately ended their own lives [4]. 85\% of the offenders were males [7,8]. Most homicide victims are female [4]. Approximately one quarter of involved persons are over the age of 55 . The medium age of offenders was 51 years in males $[7,8]$. More often (over half of the victims, 58\%), the perpetrator was a former or current husband or other intimate partner [4]. Most suicides, near $80 \%$, following a homicide/suicide incident occurred in the same place of at least one of the homicides [4]. Homicides occurred more often at the victim's home [4]. Most incidents occur in a residence $[4,8]$. Alcohol or drug use is a common risk factor in homicides. In homicide/suicide incidents, $34 \%$ of the perpetrators had detectible blood alcohol content and other substances were identifiable in $18 \%$ of the same group [3]. Male perpetrators are also more likely than victims to be under the influence of alcohol at the time of the incident [4]. Almost 30\% of perpetrators tested positive for drugs or alcohol [4]. Firearms were used in a majority of incidents for both homicides and suicides (nearly $80 \%$ ). The next most common weapon used were sharp instruments $6 \%$ [4]. In $80 \%$, the offenders used a gun for both the homicide and suicide. In $16 \%$, the offender used a different weapon for homicide and suicide [7,8]. Among firearms, handguns were more likely to be used than shotguns or rifles [8]. Among suicides, the head, face or neck were the most frequent location of the wounds with only one wound location. While the head area was also the most common location among homicide victims (72\%), a significative percentage of these had wounds in multiple locations (22\%) [4].

In the present study, considering all female victims of homicide, $54 \%$ of all intimate partner homicides were followed by suicide $(71 \%)$ or suicide attempts $(29 \%)$, the majority $(71 \%)$ with one single victim. In most cases, the male homicide perpetrator was older than the intimate partner and married to the victim. Firearms were used in most cases, to both homicide and suicide, with the same single anatomic location injuries in the head. Most homicides and suicides occurred at the victim's home.

The current results undescore the importance of: (1) prevention programs and policies for victims of intimate partner violence, (2) enforcement of existing domestic violence laws, and (3) restricting access to guns.

Additional research is needed to study and identify risk factors and precipitating events in this special type of homicide-suicide incidents, as legal, job or financial 
problems, physical health problems, mental illness, substance abuse disorders, relationship rupture, suicidal behavior and violence, in order to understand and prevent them. Another interesting study would be the correlation of homicide, suicide and homicide-suicide incidents.

\section{References}

[1] SAINT-MARTIN P, BOUYSSY M, O'BYRNE P. Homicide-suicide in Tours, France (2000-2005) - description of 10 cases and a review of the literature. J Forensic Leg Med, 15:104-109, 2008.

[2] SHANAAZ MATHEWS, NAEEMAH ABRAHAMS, RACHEL JEWKES, LORNA J MARTIN, CARL LOMBARD, LISA VETTEN. Intimate femicide-suicide in South Africa: a cross-sectional study. Bulletin of the World Health Organization,86:497-576, 2008.

[3] LECOMTE D, FORNES P. Homicide followed by suicide: Paris and its suburbs, 19911996. J Forensic, S 43(4):760-764, 1998.

[4] BOSSARTE RM, SIMON TR, BARKER L. Characteristics of homicide followed by suicide incidents in multiple states, 2003-04. Injury Prevention,12:33-38, 2006.

[5] SALEVA O, PUTKONEN H, KIVIRUUSU O, LÖNNQVIST J. Homicide-suicide - an event hard to prevent and separate from homicide or suicide. Forensic Sci Int 166:204-208, 2007.

[6] ALDRIDGE ML, BROWNE KD. Perpetrators of spousal homicide: a review. Trauma Violence Abuse 4:265-276, 2003.

[7] LUND LL, SMORODINSKY S. Violent death among intimate partners: a comparison of homicide and homicide followed by suicide in California. Suicide Life Threat Behav, 31:451-9, 2001.

[8] CHAN CY, BEH SL, BROADHURST RG. Homicide-suicide in Hong Kong, 1989-1998. Forensic Sci Int 140:261-7, 2004.

\begin{tabular}{|c|c|c|c|c|c|c|c|c|c|c|}
\hline & No. & & Gender & Age & Race & $\begin{array}{l}\text { Relationship viction' } \\
\text { fpexpetrator }\end{array}$ & $\begin{array}{l}\text { Living at the } \\
\text { same home of } \\
\text { perpetrator }\end{array}$ & Weapon used & Location and type of injury & $\begin{array}{l}\text { Place of the } \\
\text { incident }\end{array}$ \\
\hline \multirow{21}{*}{ 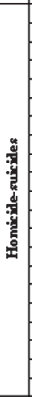 } & 1 & Pexpetrator & Male & 39 & Black & - & & Fireamn (shotgun) & Head - single & Outside home \\
\hline & & Yictim & Female & 36 & Black & Spouse by mamiaze & Yes & Firearm (shotgun) & Head - single & Outside home \\
\hline & 2 & Pexpetyator & Male & 72 & White & & - & Firearm (shotgun) & Head - single & Home \\
\hline & & Wictim & Female & 45 & White & Spouse by mamiaze & Yes & Firearn (shotgun and handgun) & Head - roultiple & Home \\
\hline & 3 & Pexpetrator & Male & 49 & White & - & - & Firearm (handgun) & Head-single & Outside home \\
\hline & & Victim & Female & 25 & White & Extramarital corsont & No & Firearm (handgun) & Head, torax, abdomen - moultiple & Outside home \\
\hline & 4 & Pexpetrator & Male & 60 & White & 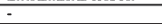 & - & Firearm (handgun) & Head-single & Outside home \\
\hline & & Victim & Ferrale & 51 & White & Extramanital oonsort & No & Firearm (handgun) & Head - single & Outside home \\
\hline & 5 & Pexpetrator & Male & 74 & White & - & - & Fireamn (shotgun) & Head-single & Home \\
\hline & & Victim & Female & 80 & White & Spouse by mamiage & Yes & Fireamn (shotgun) & Head - single & Home \\
\hline & 6 & Pexpetrator & Male & 61 & White & 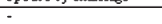 & - & Fall from height & Head, torax, abdomen, limbs - roultiple & Home \\
\hline & & Fictim & Female & 56 & White & Spouse by mamiage & Yes & Marozal strangulation & Neck - noultiple & Home \\
\hline & 7 & Pexpetrator & Male & 55 & White & & & Firearm (handzun) & Head- noultiple & Home \\
\hline & & Fictim & Female & 50 & White & Spouse by mamiage & Yes & Firearm (handgun) & Head,abdomen - multiple & Home \\
\hline & & Victim & Male & 26 & White & Son & Yes & Firearm (handgun) & Torax, abdomen - rroultiple & Home \\
\hline & 8 & Perpetrator & Male & 40 & White & F & Aes & Fireamm (shotgun) & Head - single & Home \\
\hline & & Victim & Female & 34 & White & Common-law spouse & Yes & Firearm (shotgun) & Torax - single & Home \\
\hline & & Wictim & Male & 8 & White & Son & Yes & Fireamn (shotgun) & Head-single & Home \\
\hline & 9 & Perpetrator & Male & 56 & White & 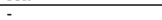 & 烈 & Firearm (handgun) & Head - single & Home \\
\hline & & Fictim & Female & 49 & White & Ex-common-law spouse & Yes & Firearm (hardgun) & Head - roultiple & Home \\
\hline & & Victim & Male & 11 & White & EX-step son & Yes & Firearm (handgun) & Head - single & Home \\
\hline \multirow{11}{*}{ 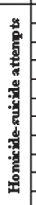 } & 10 & Pexpetrator & Male & 65 & White & 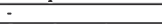 & - & Firearm (handzun) & Head-single & Home \\
\hline & & Victim & Fermale & 69 & White & Spouse by mamiage & Yes & Firearm (hardgun) & Head - single & Home \\
\hline & & Victim & Male & 34 & White & Son & Yes & Firearm (handgun) & Head - single & Home \\
\hline & 11 & Pexpetrator & Male & 47 & * & - & - & Firearm (handgun) & Head - single & Home \\
\hline & & Victim & Female & 44 & White & Spouse by mamiage & Yes & Fiream (hardgun) & Head - roultiple & Home \\
\hline & 12 & Pexpetrator & Male & 33 & & & & Firearm (hardgun) & Head - * & \\
\hline & & Yictim & Female & $\frac{1}{21}$ & White & Ex-girlfriend & No & Fireamn (hardgur) & Neck - single & Outside home \\
\hline & 13 & Pexpetrator & Male & 41 & $*$ & - & - & Sharp instrument & Limbs - moultiple & Home \\
\hline & & Victim & Female & 38 & White & Ex-spouse by marriage & Yes & Sharp instrument & Torax - moultiple & Home \\
\hline & 14 & Pexpetrator & Male & 79 & & - & - & Sharp instrument & Heck,abdomen - multiple & Home \\
\hline & & Victim & Fervale & 76 & White & Spouse by mamiage & Yes & Marazal strangulation & Neck - moultiple & Home \\
\hline
\end{tabular}

Table 1 - Comparison of perpetrator and victim(s) characteristics of homicide-suicide incidents 